\title{
Kolonoskopi ile tanı konulan, endometriozisin sebeb olduğu appendiks invajinasyonu: nadir bir olgu sunumu
}

The appendix invagination due to endometriozis diagnosed with colonoscopy: a rare case report

Yusuf YÜCEL ${ }^{1}$, Ahmet ŞEKER ${ }^{1}$, Abdullah ÖZGÖNÜL ${ }^{1}$, Alpaslan TERZI ${ }^{1}$, Timuçin AYDOĞAN², Ahmet UYANIKOĞLU², Reşit ÇIFTÇİ ${ }^{1}$, Ali UZUNKÖY1

Harran Universitesi Tip Fakültesi, ${ }^{1}$ Genel Cerrahi Anabilim Dall, ${ }^{2}$ Gastroenteroloji Bilim Dal, Şanlıurfa

Appendiks invajinasyonu çok nadir görülen bir durumdur. Bütün yaş gruplarını ve her iki cinsiyeti de etkileyebilir ancak sıklıkla 1. dekattaki erkek çocuklarında görülür. Genellikle akut apandisit ön tanıslyla ameliyat edilen hastalarda insidental olarak tanı konur. Kolonoskopi ile appendiks invajinasyonu tanısı rastlantısal olarak konulabilir. Çekumdaki poliplerle karışabileceği için endoskopistlerin bu duruma dikkat etmeleri gerekir. Olgumuz 45 yaşında, 1 yıldır aralıklı karın ağrısı olan kadın hasta idi. Hastanın kolonoskopik muayenesinde appendiks invajinasyonu olabileceği düșünüldü. Kitle cerrahi olarak çekumdan wedge rezeksiyonu ile çıkarıldı. Kitle çevresi fibrotik, mavi-siyah rekli görünümdeydi. Sonuç olarak, appendiks invajinasyonu nadir görülen bir durum olup, preoperatif dönemde yapılan kolonoskopi tanı koymaya yardımcı olabilir.

Anahtar kelimeler: Appendiks, invajinasyon, kolonoskopi

\section{GİRIŞ}

Appendiks invajinasyonu çok nadir görülen bir durumdur, otopsi serilerinde yaklaşık \%0,01 sıklı̆̆ında tespit edilmiştir $(1,2)$. Bütün yaş gruplarını etkileyebilir ancak sıklıkla ilk dekattaki erkek çocuklarında görülür $(3,4)$. Hastalar akut ya da kronik karın ağrisıyla doktora başvurabilirler $(1,2,5,6)$. Ameliyat etmeden, bu hastalara tanı koymak zordur $(2,3,6)$. Genellikle akut apandisit düşünülerek ameliyat edilen hastalarda insidental olarak tanı konur (1). Appendiks invajinasyonu tanısında kolonoskopi kullanılabilir. Ancak kolonoskopide dikkat edilmesi gereken nokta invajinasyon olgularının yanlışlıkla çekum polipleri ile karıştırılabilmesidir $(2,6)$. Olgu sunumumuzda karın ağrısı şikayeti ile başvuran ve invajinasyon tanısı konulan bir olgunun tanı ve tedavisi tartışılmıştır.

\section{OLGU SUNUMU}

Olgumuz 45 yaşında bir kadın hasta olup 1 yıldır tekrarlayan karın ağrları mevcuttu. Fizik muayene normaldi. Laboratuvar bulguları normal olup şu şekildeydi: glukoz $104 \mathrm{mg} / \mathrm{dl}$, üre $25 \mathrm{mg} / \mathrm{dl}$, kreatinin $0,48 \mathrm{mg} / \mathrm{dl}$, aspartat aminotransferaz $30 \mathrm{U} / \mathrm{L}$, alanin aminotransferaz $18 \mathrm{U} / \mathrm{L}$, C-reaktif protein $0,03 \mathrm{mg} / \mathrm{dl}$, lökosit sayısı $5.234 \mathrm{uL}$, hemoglobin $12,79 \mathrm{~g} / \mathrm{dl}$, hematokrit \%41.13, trombosit sayısı $283.000 \mathrm{uL}$. Abdominal ultrasonografi normal olarak rapor edildi. Hastaya endoskopi ünitemizde yapılan kolonoskopide çekumda, appendiks
Appendix invagination is a rare condition. It can be seen in both males and females at every age but is seen primarily in males during the first decade of life. Diagnosis is generally made incidentally on patients who are operated on with the suspected preliminary diagnsosis of acute appendicitis. Colonoscopy may be incidentally diagnosed with appendiceal invagination. Endoscopists should be careful because it is possible to come across with caecum polyps. We report on a case concerning a female patient who had occasional abdominal pain. Invagination of the appendix was suspected following colonoscopic examination. The mass was excised with wedge resection. The mass surroundings were fibrotic and blue-black in color. In conclusion, appendix invaginaton is a rare situation and perioperative colonoscopy might be helpful in its diagnosis.

Key words: Appendix, invagination, colonoscopy

orifisi lokalizasyonunda, 1-2 cm çapında, düzgün, sapsız polipoid görünümlü kitle tespit edildi (Resim 1-2). Bu kitle, appendiks orifisinin görülmemesi sebebiyle appendiks invajinasyonu olarak değerlendirildi ve hastaya cerrahi planlandı. Genel anestezi altında Mc Burney insizyonla batına girildi, appendiks bulunamadi. Appendiks lokalizasyonunda çekum lümenine uzanan $2 \mathrm{~cm}$ çapında çevresi fibrotik, mavi-siyah renkli kitle palpe edildi, bu kitle wedge rezeksiyonla çıkarıldı. Frozen incelemenin 'benign appendiks patolojisi' rapor edilmesi üzerine ameliyat sonlandırıldı. Nihai patolojik değerlendirmede ise, 'appendiks lümeninde endometriozis ile uyumlu doku' tespit edildi. Yapılan kısa dönem kontrollerde herhangi bir olumsuz durumla karşılaşılmadı. Hasta operasyon sonrasında uzun dönem takibe alındı.

\section{TARTISQMA}

Appendiks invajinasyonunu ilk olarak, McKidd 1858 yılında, 7 yaşındaki bir erkek çocuğunda tanımladı. 1964 yılında Collins ve arkadaşları 71.000 kadavradan alınan ve cerrahi olarak hastalardan çıkarılan appendiksleri inceledi. Appendiks invajinasyonunun sıklığ1 \%0,01 olarak tespit edildi. Bu çalışma sonucunda, her yaşta görülebilebilmekle birlikte vakaların, çoğunlukla ilk dekattaki çocuklar olduğu görüldü. Erkek/kadın oranı 4/1 idi (7). 


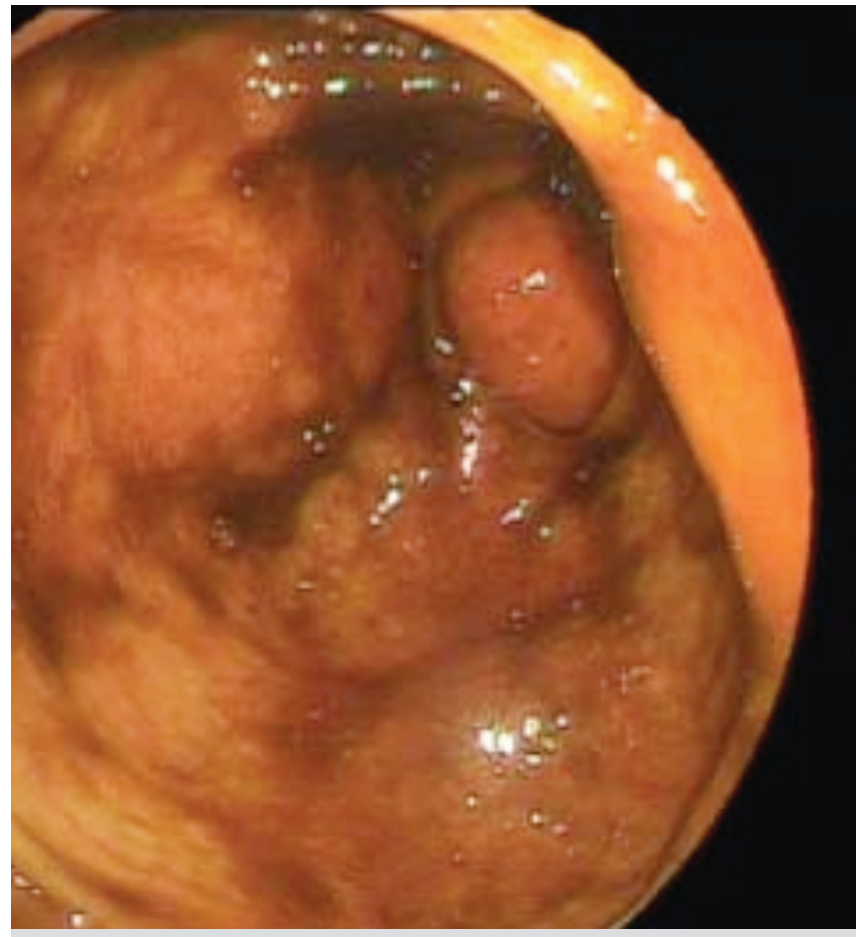

Resim 1. Kolonoskopide çekum ve invajine appendiks.

Genellikle hastayı ameliyat etmeden appendiks invajinasyonu tanısını koymak zordur. Hastalarda kronik ya da tekrar eden karın ağnısı, rektal kanama, barsak alışkanlığında değişiklikler olabilir veya hiçbir belirti olmayabilir. En sık da akut apandisiti taklit eder $(1,5,7)$

Bizim olgumuz da, son 1 yıldır tekrarlayan karın ağrıları olan 45 yaşında bir kadın hasta idi.

Literatürde çok az olguya endoskopik tanı konulabilmiştir. Endoskopik olarak, appendiksin anatomik olarak bulunduğu noktada, polipoid ya da mantar şeklinde bir görünüm olabilir (1). Vakamızda da endoskopik görünüm polip şeklindeydi, appendiks orifisinin de görülmemesi appendiks invaginasyonu olabileceğini akla getirdi.

Appendiks invajinasyonunun patogenezi bilinmemektedir. Bazı vakalarda meydana gelebilen, appendiks ve çekumdaki irritasyonun peristaltizm artışına sebep olduğu, bunun da appendiks invajinasyonunu tetiklediği düşünülmektedir (7).

\section{KAYNAKLAR}

1. Tavakkoli H, Sadrkabir SM, Mahzouni P. Colonoscopic diagnosis of appendiceal intussusception in a patient with intermittent abdominal pain a case report. World journal of gastroenterology. World J Gastroenterol 2007;13:4274-7.

2. Ryu BY, Kim TH, Jeon JY, et al. Colonoscopic diagnosis of appendiceal intussusception: a case report. J Korean Med Sci 2005;20:680-2.

3. Seddik H, Rabhi M. Two cases of appendiceal intussusception: a rare diagnostic pitfall in colonoscopy. Diagn Ther Endosc 2011;2011:198984.

4. Ijaz S, Lidder S, Mohamid W, et al. Intussusception of the appendix secondary to endometriosis: a case report. J Med Case Rep 2008;2:12.

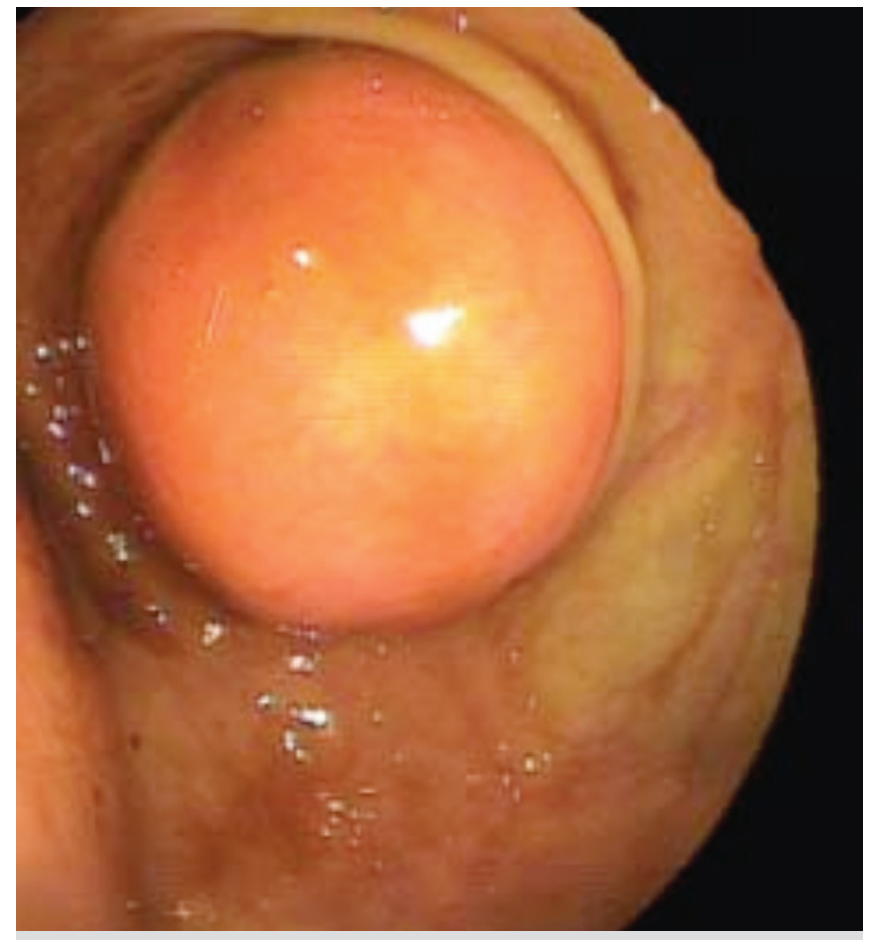

Resim 2. Kolonoskopide çekum ve invajine appendiks.

Irritasyonun muhtemel sebepleri arasinda, yabanci cisim, parazit, polip, lenfoid hiperplazi, endometriozis, adenokarsinom, karsinoid tümör, mukosel bulunabilir. Anatomik olarak appendiks lümeninin geniş olması ve mobil mezoapendiks de bu irritasyona yol açabilir $(1,5,7)$. Bizim olgumuzda da, yapılan patolojik değerlendirme sonucunda, appendiks invajinasyonunu tetikleyen etkenin endometriozis olduğu bulundu.

Açıklanamayan karın ağrıları olan hastalarda, radyolojik şüphe de mevcutsa, appendiks invajinasyonu tanısı için kolonoskopi bize çok değerli ipuçları verebilir. Kolonoskopide appendiks orifisi dikkatli bir şekilde değerlendirilmelidir. Aksi takdirde, appendiks ağzındaki invajinasyon, polip ya da malign bir kitle kabul edilerek polipektomi veya biyopsi alma işlemi yapılabilir. Semptomsuz hastalar takip edilebilirken, malignite şüphesi olan ve semptomatik olgularda ise cerrahi en doğru yaklaşımdır.

5. Thomas RE, Maude K, Rotimi O. A case of an intussuscepted neuroendocrine carcinoma of the appendix. World J Gastroenterol 2006;12:9713.

6. Akbayir N, Yildirim S, Sokmen HM, et al. Intussusception of vermiform appendix with microscopic melanosis coli: a case report. Turk J Gastroenterol 2006;17:233-5.

7. Salehzadeh A, Scala A, Simson JN. Appendiceal intussusception mistaken for a polyp at colonoscopy: case report and review of literature. Ann R Coll Surg Engl 2010;92:W46-8. 